\title{
PENGENALAN VAKSINASI HPV OLEH KOALISI INDONESIA CEGAH KANKER SERVIKS DENGAN PENDEKATAN TEORI DIFUSI INOVASI
}

\author{
Aldila Maharani Sutjipto, Janette Maria Pinariya \\ London School of Public Relations, Jakarta \\ aldilamaharani92@gmail.com \\ Diajukan: 18-09-2019; Direview: 30-10-2019; Diterima: 17-12-2019;
}

\begin{abstract}
This study discusses public relations campaigns in the health sector conducted by KICKS (Koalisi Indonesia Cegah Kanker Serviks) as an effort to introduce HPV vaccination as a primary prevention of cervical cancer. Used case study method with a descriptive qualitative approach, the research aims to obtain information about strategies used in introducing innovations in the health sector, obstacles faced and how to deal with them. By analyzing the main elements of diffusion of innovation, supported by public relations concept and health communication, the results of this study show that KICKS has considered 4 main elements of diffusion of innovation, which include, innovation, communication channels, time, and the social system. Where KICKS public relations form a strategy by maximizing the use of opinion leaders. Using mass media, new media, and interpersonal communication as the communication channel. The messages are also formed by considering the characteristics of innovation, and for now, the HPV vaccination introduction by KICKS is generally at the persuasion stage in the innovation-decision process.
\end{abstract}

Keywords: Health Communication, HPV Vaccination, Diffusion of Innovation.

\begin{abstract}
Abstrak
Penelitian ini membahas kampanye humas di bidang kesehatan yang dilakukan oleh KICKS (Koalisi Indonesia Cegah Kanker Serviks) sebagai salah satu upaya guna mengenalkan vaksinasi HPV sebagai pencegah primer kanker serviks. Menggunakan metode studi kasus dengan pendekatan kualitatif deskriptif, penelitian bertujuan untuk memperoleh informasi mengenai strategi yang sesuai dalam mengenalkan inovasi di bidang kesehatan, hambatan yang dihadapi dan cara menghadapinya. Dengan menganalisa elemen utama difusi inovasi, didukung konsep public relations dan komunikasi kesehatan, hasil penelitian menunjukan bahwa KICKS telah mempertimbangkan 4 elemen utama difusi inovasi, yang terdiri dari inovasi, saluran komunikasi, waktu, dan sistem sosial. Di mana humas KICKS membentuk strategi dengan memaksimalkan penggunaan opinion leader. Menggunakan media massa, new media dan komunikasi interpersonal sebagai saluran komunikasi. Pesan juga diolah dengan mempertimbangkan karakteristik inovasi, dan pada saat ini pengenalan vaksinasi HPV oleh KICKS umumnya baru masuk ke dalam tahap persuasi di dalam proses keputusan inovasi.
\end{abstract}

Kata Kunci: Komunikasi Kesehatan, Vaksinasi HPV, Difusi inovasi.

\section{PENDAHULUAN}

$\mathrm{K}$ anker serviks merupakan salah satu jenis kanker mematikan yang menyerang organ leher rahim, menjadi kanker nomor dua yang menyebabkan kematian pada wanita di dunia (Budiwati, 2012), dan nomor dua di Indonesia (Yudhani et al, 2019). Diperkirakan setiap tahunnya terdapat 32.469 wanita Indonesia didiagnosis kanker serviks, dan 18.279 meninggal akibat penyakit ini (HPV Information Center,
2018).Data mengkhawatirkan lainnya adalah prediksi dari World Health Organization (WHO) yang memperkirakan bahwa angka kematian akibat kanker serviks akan mengalami peningkatan sebesar hampir 50\% di tahun 2030 (Ghebreyesus, 2018).

Penyebab kanker serviks 99,7 persen disebabkan oleh infeksi Human Papiloma Virus (HPV), virus ini menginfeksi serviks melalui kontak seksual, dan infeksi HPV umumnya tidak 
menimbulkan gejala apapun pada penderitanya. Kanker serviks adalah penyakit yang tidak sama dengan penyakit kanker lainnya sebab kanker serviks dapat di cegah dan jika terdeteksi lebih awal dapat disembuhkan 100 persen (Budiwati, 2012). Vaksin HPV sebagai pencegah primer kanker serviks mendapat izin pertama kali pada tahun 2006 dan direkomendasikan oleh WHO untuk di masukan ke dalam program imunisasi nasional dengan kelompok sasaran primer nya adalah anak perempuan berusia 9-14 tahun, karena pada usia ini umumnya anak belum aktif secara seksual (Savitri, 2015).

Akan tetapisangat disayangkan bahwakehadiran vaksin HPV yang dapat menjadi solusi dalam pencegahan kanker serviks belum dimanfaatkan secara maksimal di Indonesia. Masih banyak masyarakat belum mengenal dan memahami apa itu kanker serviks dan pentingnya melakukan vaksinasi HPV (National Cancer Institute, 2016). Pada umumnya hal ini terjadi karena minimnya tingkat pengetahuan dan pemahaman mengenai kanker serviks (Departemen Kesehatan, n. d). Belum banyak penyebaran informasi terkait pengenalan vaksinasi HPV di Indonesia (Budiwati, 2012), hal ini tentu sangat disayangkan melihat telah hadirnya solusi pencegah dan tingginya angka kematian akibat kanker serviks.

Faktor lainnya adalah karena biayanya yang tergolong mahal, yaitu berkisar antara $\mathrm{Rp}$ 600.000-Rp 800.000 untuk vaksin HPV bivalent dan Rp 1.100.000-Rp 1.300.000 untuk vaksin HPV quadrivalent (Wiyanti, 2017). Belum dilaksanakannya program vaksinasi HPV di Indonesia disebabkan juga oleh faktor harga yang menjadi penghambat di negara dengan sumber dana terbatas (Dewi, 2017). Di beberapa negara maju di mana program pencegahan telah dilaksanakan dengan baik, angka kejadian kanker serviks dapat diturunkan sebanyak $65 \%$ dalam 40 tahun setelah dilaksanakan program. Beberapa orang juga menolak pemberian vaksin HPV karena sikap skeptis yang terbentuk berdasarkan berbagai faktor, seperti banyaknya tersebar berita bahwa vaksin HPV dapat menyebabkan menopause dini, risiko meningkatnya beberapa penyakit yang berhubungan dengan saraf dan penyakit lainnya. Sebagian juga masih menganggap pemeriksaan kanker sebagai hal yang tabu, memalukan dan menyeramkan (International Pharmaceutical Manufacturers Group, n. d).

Berdasarkan hasil penelitian sebelumnya, state of the art, ditemukan bahwa di Hongkong, sejumlah persepsi sosial dan budaya menjadi faktor pencegah anak perempuan untuk menerima vaksin (Siu, 2014). Para ibu sebagai peserta tidak memiliki persepsi positif tentang vaksin HPV, mereka juga memiliki banyak kesalahpahaman, dan kurangnya dukungan dari penyedia layanan kesehatan juga otoritas kesehatan pemerintah mengenai vaksinasi HPV menyebabkan kegagalan penyampaian makna kepada para ibu. Data menunjukkan bahwa dibutuhkan pendidikan lebih lanjut terkait risiko HPV dan jaminan tentang vaksin, sehingga mereka dapat mengirimkan pesan yang lebih positif kepada anak perempuannya dalam melakukan tindakan kesehatan preventif ini. Tantangan dalam penerimaan vaksin HPV juga terjadi di Tanzania, di mana berdasarkan hasil penelitian Remes et al (2012) ditemukan bahwa guru, orang tua, murid dan petugas kesehatan yang diwawancarai tidak memiliki pengetahuan atau pemahaman yang sangat terbatas terkait kanker serviks, HPV, dan vaksin HPV. Temuan ini serupa dengan hasil penelitian formatif oleh PATH (Program for Appropriate Technology in Health) di Uganda, Peru, Vietnam, India, Ghana, Botswana, Kenya, dan Afrika Selatan terkait vaksinasi HPV. Untuk menyelenggarakan program nasional yang sukses terkait pencegahan kanker serviks, dibutuhkan sosialisasi melalui pertemuan sekolah, masyarakat dan media massa, dengan semua populasi yang relevan. Hal serupa juga menjadi tantangan bagi pemerintah Indonesia, berdasarkan hasil penelitian Ayuningtyas \& Sutrisnawati (2018) ditemukan bahwa kesadaran masyarakat terkait vaksin HPV masih minim, terdapat beberapa faktor yang menjadi penghalang, yaitu harga yang relatif tinggi, ketakutan akan efek samping, seksualitas, gender, dan sistem perawatan kesehatan. Pelaksanaan proyek percontohan vaksinasi HPV gratis telah dilaksanakan, akan tetapi penyesuaian dan dukungan dari pemerintah masih dibutuhkan dalam memberikan informasi yang baik tentang vaksin HPV kepada masyarakat.

Berdasarkan urgensi paparan di atas maka 
berbagai usaha, strategi, peran dan profesi dibutuhkan, termasuk salah satunya peran seorang humas untuk membantu membentuk berbagai strategi guna memperkenalkan lebih lanjut, menciptakan pemahaman, membujuk, mengurangi ketidak pastian, dan meningkatkan kesadaran terkait kanker serviks dan vaksin HPV. Kegiatan atau kampanye yang di lakukan oleh humas dengan mengangkat sebuah isu yang sedang berkembang dikalangan masyarakat sendiri saat ini sedang marak dilakukan oleh banyak perusahaan, mereka berlomba untuk ikut andil dalam mengkomunikasikan berbagai isu yang ada kepada masyarakat guna menumbuhkan kesadaran dan bersama-sama ikut andil dalam mencari solusi dari isu tersebut (Anggaini, 2014). Akan tetapi di tengah kondisi ini, satu-satunya organisasi nonprofit yang paling aktif dan fokus dalam menyuarakan mengenai kanker serviks dan pentingnya vaksinasi HPV di Indonesia adalah Koalisi Indonesia Cegah Kanker Serviks (KICKS), didirikan oleh beberapa organisasi, baik dari kalangan medis maupun nonmedis pada April 2017, dengan tujuan akhir untuk mendukung upaya memasukan vaksinasi HPV kedalam program imunisasi nasional(Koalisi Indonesia Cegah Kanker Serviks, n. d) Melalui kampanye humas bernama CegahKankerServiks, KICKS melakukan beragam kegiatan, baik secara online maupun offline.

Kajian ini menggunakan pendekatan teori difusi inovasi dari Everett M. Rogers, dengan berfokus pada empat elemen utama nya, yang terdiri dari inovasi, saluran komunikasi, waktu dan sistem sosial (Rogers, 2003). Pendekatan dengan menggunakan teori ini dianggap sesuai dengan pembahasan yang ada, karena dapat dibahas secara mendalam mengenai bagaimana suatu ide, pemikiran, sudut pandang, objek, maupun karya baru dikomunikasikan agar diadopsi oleh anggota sistem sosial. Ini juga didasari pada pemikiran bahwa keberhasilan penerapan suatu ide akan sangat bergantung pada proses komunikasi yang dilakukan.

Berdasarkan latar belakang diatas, maka dirumuskan permasalahan sebagai berikut: Bagaimana strategi pengenalan vaksinasi HPV oleh KICKS (Koalisi Indonesia Cegah Kanker Serviks) dengan pendekatan teori difusi inovasi?
Adapun kajian ini bertujuan untuk mendeskripsikan mengenai strategi pengenalan vaksinasi HPV oleh KICKS dengan menggunakan pendekatan teori difusi inovasi, hambatan yang dihadapi dan cara menghadapinya. Kajian ini diharapkan dapat memberikan informasi terkait strategi yang sesuai dalam mengenalkan inovasi di bidang komunikasi kesehatan kepada masyarakat Indonesia sebagai upaya pencegahan penyakit.

\section{LITERATUR DAN METODOLOGI}

\section{Difusi Inovasi}

Teori difusi inovasi dari Everett M Rogers membahas mengenai bagaimana seiring berkembangnya zaman, muncul beragam inovasi di berbagai bidang, dan kehadiran inovasi tersebut memerlukan difusi agar bisa diterima oleh masyarakat luas. Inovasi sendiri di definisikan oleh Rogers (2003) sebagai ide, kegiatan atau objek yang memiliki unsur kebaruan di dalamnya. Kebaruan yang dimaksud di sini dilihat berdasarkan reaksi individu, jika suatu gagasan terlihat baru bagi individu, hal tersebut dapat dikategorikan sebagai sebuah inovasi. Sedangkan difusi dijelaskan sebagai proses di mana suatu inovasi dikomunikasikan melalui beragam saluran komunikasi dalam jangka waktu tertentu kepada anggota sistem sosial. Difusi dapat dikatakan juga sebagai tipe komunikasi khusus di mana pesannya merupakan ide baru (Rizal, 2012).

Difusi inovasi tidak hanya terjadi begitu saja, terdapat empat elemen utama yang akan mempengaruhi satu sama lain, dan menentukan apakah sebuah inovasi dapat diterima oleh unit penerima adopsi pada akhirnya, yaitu inovasi, waktu, saluran komunikasi, dan sistem sosial (Rogers, 2003).Berikut adalah pembahasan lebih lanjut mengenai ke empat elemen tersebut (2003)

Inovasi, secara umum dipahami sebagai konteks yang melibatkan perubahan perilaku (Suwarno, n. d). Suatu inovasi tidak seharusnya diasumsikan sebagai hal yang setara, karena inovasi yang berbeda akan membutuhkan usaha atau difusi yang berbeda. Berikut adalah beberapa karakteristik yang paling penting dari inovasi dalam menjelaskan tingkat adopsi, diantaranya adalah (Rogers, 2003) relative advantage, compatibility, complexity, 


\section{trialability, observability.}

Saluran komunikasi, Digambarkan sebagai penghubung antara komunikator dan komunikan guna menyampaikan pesan (Rogers, 2003). Di kelompokan menjadi dua, yaitu media massa dan komunikasi interpersonal, dengan kekurangan dan kelebihannya masing-masing

Waktu, merupakan elemen penting lainnya dalam proses difusi inovasi, Rogers (2003) menjelaskan bahwa pengukuran waktu dapat dilihat melalui beberapa faktor, diantaranya adalah melalui proses keputusan inovasi, yang terdiri dari lima tahap, yaitu knowledge, persuasion, decision, implementation, confirmation.

Sistem sosial, didefinisikan sebagai sekumpul unit yang saling berhubungan dan terlibat dalam pemecahan masalah untuk mencapai tujuan (Rogers, 2003). Sistem sosial merupakan batas di mana sebuah inovasi berdifusi, anggota atau unit sistem sosial dapat berupa individu, kelompok informal, organisasi, dan subsistem. Teori ini melihat bahwa inovasi dapat terdifusi melalui model yang dapat diperkirakan, sebagian orang akan mengadopsi sebuah inovasi segera setelah mereka mendengar inovasi tersebut dan sebagian yang lain membutuhkan waktu lebih. Di dalam elemen sistem sosial di bahas juga mengenai beragam hal, termasuk peran dari opinion leader dan agen perubahan.

\section{Komunikasi Kesehatan}

Menurut Thomas (dalam Wilujeng \& Handaka, 2017) komunikasi kesehatan meliputi semua pembelajaran dan pengunaan strategi komunikasi untuk memberikan informasi dan mempengaruhi pengetahuan, sikap, dan perilaku masyarakat terkait kesehatan. Komunikasi kesehatan dapat berkontribusi untuk seluruh aspek penanggulangan penyakit dan promosi kesehatan, meningkatkan kesadaran individu tentang isu-isu, masalah, resiko, serta solusi kesehatan (Rahmadiana, 2012). Komunikasi kesehatan pada umumnya bersifat rumit karena dibutuhkan pemahaman mendalam akan penyakit yang ada dan seringkali disalahpahami karena menggunakan istilah atau kata yang kompleks dan jarang dikenal, kata kompleks yang dimaksud di sini adalah kata-kata yang tidak digunakan dalam pembicaraan seharihari, bahkan ketika seseorang membicarakan tentang kesehatan (Parrott, 2009). Memiliki peran penting dalam meningkatkan kesadaran individu, karena kebanyakan penyakit dewasa ini disebabkan oleh kurangnya wawasan dan akses kesehatan.

\section{Metodologi Penelitian}

Untuk menjawab rumusan masalah, penulis menggunakan metode studi kasus dengan pendekatan deskriptif kualitatif, yang memusatkan penelitian pada suatu unit tertentu dari berbagai fenomena, yakni kegiatan pengenalan vaksinasi HPV oleh KICKS. Metode ini dinilai dapat memberikan gambaran konsep dan rancangan guna memberikan informasi mendalam tentang tema atau topik penelitian. Penelitian dilaksanakan di daerah JABODETABEK, mengingat saat ini kegiatan dan kantor KICKS masih berfokus di sana. Penelitian di mulai pada bulan Agustus 2018 sampai Maret 2019. Menggunakan pendekatan teori difusi inovasi dari Everett M. Rogers, dengan berfokus pada empat-elemen utamanya, yang terdiri dari inovasi, saluran komunikasi, waktu dan sistem sosial (Rogers, 2003).

Teknik pengumpulan data dalam penulisan ini dilakukan dengan menggunakan metode wawancara semi terstruktur dan studi pustaka. Wawancara dilakukan terhadap narasumber yang dianggap paling mengetahui dan memahami kegiatan pengenalan vaksinasi HPV oleh KICKS. Adapun pihak-pihak yang dipilih menjadi informan dalam penulisan ini adalah Sondang Butar Butar (humas KICKS), Novi Henriatika (humas KICKS), Listyowati (anggota KICKS), Dr. Ardiansjah Dara Sjahruddin (dokter spesialis kandungan), Levina Masli (masyarakat), dan Citra Pulandi Utomo (masyarakat). Sedangkan untuk studi pustaka di dapatkan penulis dari berbagai sumber yang sudah ada, baik itu berupa buku, jurnal, skripsi, koran, majalah, internet dan lainnya, guna memperkuat dan melengkapi informasi yang didapatkan dari hasil wawancara.

Keabsahan interpretasi data dilakukan melalui triangulasi sumber, dengan cara membandingkan data yang deperoleh melalui beberapa sumber. Untuk teknik analisis data penulis menggunakan model Miles dan Huberman (dalam Afrizal, 2014) 
yang dibagi kedalam tiga tahap, yaitu kodifikasi data, penyajian data, dan penarikan kesimpulan. Ketiga tahap ini berlangsung secara siklus, dari tahap satu sampai tiga dan kembali lagi ke tahap satu.

\section{TEMUAN DAN DISKUSI}

Guna meningkatkan awareness terkait kanker serviks dan vaksinasi HPV, humas KICKS secara aktif membentuk berbagai strategi, yang dilakukan melalui kampanye kehumasan bernama CegahKankerServiks. Terdiri dari beragam kegiatan, diantaranya adalah sebagai berikut (Koalisi Indonesia Cegah Kanker Serviks, n. d): Pertama, penggunaan opinion leader, terdiri dari beragam pihak, mulai dari selebriti (duta kanker serviks), ahli kanker, ahli kandungan, dan lainnya yangberperansebagaikomunikator.Kedua, edukasi, dilakukan melalui beragam saluran komunikasi di berbagai lokasi, seperti diantaranya terdapat online clinic di media sosial, penyuluhan di Ruang Publik Terpadu Ramah Anak (RPTRA), sekolah, rumah sakit, perusahaan, dan pusat perbelanjaan. Ketiga, kerja sama, KICKS memiliki anggota yang terdiri dari berbagai pihak yang dianggap berpengaruh dalam menyuarakan mengenai kanker serviks dan vaksin HPV, baik medis maupun nonmedis. Keempat, penyelenggaraan layanan vaksinasi HPV, membentuk beragam kegiatan guna memudahkan masyarakat melakukan vaksinasi HPV, seperti program vaksin yang bisa dilakukan dirumah, promo vaksin HPV, pembayaran vaksin yang bisa di cicil, informasi lokasi pemberian vaksin, dan lainnya.

Keberhasilan penyebaran dan penerapan suatu inovasi agar diadopsi oleh masyarakat tidak terlepas dari strategi yang diterapkan (Setianto, 2016), maka dari itu rangkaian kegiatan dalam kampanye CegahKankerServiks menjadi faktor penting. Kegiatan pengenalan vaksinasi HPV oleh KICKS sendiri dapat dikategorikan sebagai difusi inovasi, karena telah sejalan dengan definisi, dan karakteristik yang dijelaskan oleh Rogers (2003). Berikut adalah pembahasan lebih lanjut terkait hasil analisis pada ke empat elemen utama yang menjadi fokus penelitian.

\section{Inovasi}

Elemen pertama yang di teliti adalah inovasi. Inovasi yang dimaksud di sini adalah vaksinasi HPV sebagai sebuah objek yang memiliki unsur kebaruan di dalamnya. Terdapat beberapa karakteristik yang paling penting dari inovasi dalam menjelaskan tingkat adopsi, vaksinasi HPV sendiri telah memiliki karakter tersebut dan humas KICKS telah mengomunikasikannya dalam kampanye kehumasan, berikut adalah penjelasan secara lebih langsung terkait karakteristik tersebut:

Observability, membahas sejauh mana hasil dari suatu inovasi dapat dilihat, semakin mudah bagi individu untuk melihat hasil dari sebuah inovasi, semakin besar kemungkinan adopsi (Rogers, 2003). Vaksinasi HPV, pada umumnya tidak memiliki karakteristik observasi, karena vaksin ini ditujukan sebagai pencegahan, sehingga dampak ataupun hasilnya tidak dapat dirasakan atau dilihat secara langsung. Akan tetapi guna mengangkat karakteristik ini, salah satu strategi yang dilakukan oleh humas KICKS adalah dengan secara aktif membagikan pengalaman dari para penderita, melalui berbagai saluran komunikasi, salah satunya di website KICKS, terdapat halaman 'cerita mereka'. Dengan ini, masyarakat dapat memiliki gambaran dan melakukan observasi secara lebih lanjut mengenai apa yang dapat terjadi bila mereka tidak melakukan vaksinasi HPV. Dalam menjelaskan karakteristik observability, humas KICKS memaksimalkan penggunaan opinion leader yang telah dikenal oleh banyak masyarakat, sehingga lebih mudah untuk membangun kepercayaan, menyampaikan pesan, dan melakukan observasi.

Relative Advantage, membahas sejauh mana keuntungan yang ditawarkan oleh suatu inovasi (Rogers, 2003). Tingkat keuntungan dapat diukur dari faktor ekonomi, kedudukan sosial, kenyamanan, dan kepuasan. Vaksinasi HPV sendiri memiliki karakteristik ini, dilihat dari segi ekonomi, akan menguntungkan apabila individu mengeluarkan uang untuk melakukan vaksinasi HPV, dibandingkan biaya yang harus dikeluarkan apabila sudah terkena kanker serviks, atau penyakit terkait lainnya. Keuntungan juga 
dapat dilihat dari sisi sosial, dengan melakukan pencegahan individu telah melakukan investasi kesehatan. Guna meyakinkan anggota sistem sosial secara lebih jauh terkait karakteristik ini, humas KICKS selalu menyampaikan informasi terkait beragam keuntungan yang akan diperoleh apabila melakukan vaksinasi HPV, baik yang bersifat materi maupun sosial.

Complexity, membahas sejauh mana suatu inovasi dianggap sulit dipahami dan diterapkan. Inovasi yang sulit dipahami oleh sebagian besar anggota sistem sosial akan diadopsi secara lebih lambat (Rogers, 2003). Seperti yang diketahui bahwa komunikasi kesehatan pada umumnya bersifat rumit (Parrott, 2009). Hal ini juga berlaku dalam konteks memperkenalkan vaksinasi HPV sebagai suatu inovasi, terdapat banyak istilah medis yang cukup rumit dan sulit dipahami. Untuk mengatasi permasalahan tersebut, humas KICKS berusaha menyesuaikan pembicara dengan penerima pesan, sehingga pesan dapat diterima dan dipahami dengan lebih mudah. KICKS menganggap bahwa pengenalan vaksinasi HPV tidak akan menjadi sesuatu yang kompleks selama pesan yang ada diolah sedemikian rupa dan komunikator disesuaikan dengan target khalayak yang ada.

Compatibility, adalah sejauh mana suatu inovasi dianggap sejalan dengan nilai yang ada, pengalaman masa lalu, dan kebutuhan pengadopsi (Rogers, 2003). Dalam hal ini vaksinasi HPV telah memiliki karakteristik compatibility, karena masih tergolong ke dalam kelompok inovasi yang sejalan dengan nilai-nilai yang ada di Indonesia, sebagai anggota sistem sosial. Diantaranya dapat dilihat dari penjelasan Majelis Ulama Indonesia (MUI) yang menyatakan bahwa vaksin HPV tidak haram (Departemen Kesehatan, n. d), hal ini sejalan dengan nilai yang berlaku di Indonesia, melihat mayoritas masyarakat beragama islam. Dalam mengenalkan vaksinasi HPV, faktor ini juga menjadi pertimbangan humas KICKS, melihat di Indonesia isu seputar kesehatan reproduksi masih menjadi hal yang sensitif, karena adanya konflik antara nilai tradisi Indonesia dengan globalisasi ke barat-baratan yang dianggap muncul seiring adanya pendidikan kesehatan reproduksi (Benita, 2012). N. Henriatika (komunikasi pribadi, 13
Februari, 2019) menjelaskan bahwa humas KICKS akan memilah terlebih dahulu narasumber yang sesuai, melakukan brief tentang pesan yang akan disampaikan, pemilihan kata dan gambar juga menjadi pertimbangan, guna membentuk pesan yang sejalan dengan nilai yang berlaku di berbagai kelompok masyarakat Indonesia.

Triability, dijelaskan oleh Rogers (2003) bahwa pada umumnya individu tidak akan mengadopsi suatu inovasi tanpa melakukan uji coba terlebih dahulu. Vaksinasi HPV sebagai suatu inovasi sendiri telah memiliki karakteristik triability, karena sebelum diresmikan, data dari berbagai uji coba telah menunjukkan efektivitas tinggi dari kedua vaksin tersebut. Studi keamanan juga dilakukan pada ribuan wanita di seluruh dunia sebelum pemberian lisensi atau diresmikan dan hasilnya menunjukkan bahwa kedua vaksin dapat ditoleransi dengan baik tanpa adanya masalah keamanan (Centers for Disease Control and Prevention, 2013). Rogers menjelaskan bahwa uji coba tidak harus dilakukan secara langsung oleh semua individu, akan tetapi uji coba yang dilakukan oleh orang yang dikenal maupun pemimpin opini akan cukup menjadi semacam uji coba perwakilan untuk meyakinkan individu akan suatu inovasi. Di sini Magill dan Rogers (dalam Rogers, 2003) menambahkan bahwa agen perubahan seringkali dapat mempercepat proses inovasi bagi individu dengan melalui kegiatan demonstrasi ide baru di dalam sistem sosial, kegiatan ini dibuktikan dapat memberikan dampak yang efektif, terutama jika demonstran itu adalah pemimpin opini. Dalam konteks masyarakat Indonesia sebagai anggota sistem sosial, sejalan dengan pendapat ahli, humas KICKS telah melakukan hal serupa, di mana duta kanker serviks yang terdiri dari berbagai selebriti tanah air telah melakukan uji coba perwakilan.

Berdasarkan pernyataan-pernyataan tersebut, penulis menyimpulkan bahwa vaksinasi HPV telah memiliki beragam karakteristik yang dapat menentukan tingkat adopsi. Dampak atau hasil dari vaksinasi HPV dapat diobservasi dari pengalaman para penderita, uji coba juga telah dilakukan secara cukup luas baik didalam maupun diluar Indonesia, vaksin juga memiliki keuntungan yang ditawarkan terutama dalam segi ekonomi dan sosial, dan sejalan dengan nilai yang berlaku di Indonesia. 
Di sini humas KICKS membantu menyampaikan informasi dan mendukung beragam karakteristik vaksinasi HPV sebagai suatu inovasi. Yaitu diantaranya dengan mengolah pesan sedemikian rupa agar mudah dimengerti, dapat dipahami, sejalan dengan nilai, norma, dan kepercayaan yang berlaku di Indonesia. Dijelaskan juga keuntungan yang dapat diperoleh, baik dari sisi ekonomi, medis dan sosial. Selain itu dilakukan uji coba perwakilan oleh duta kanker serviks.

\section{Saluran Komunikasi}

Elemen selanjutnya yang diteliti adalah saluran komunikasi. Dalam teori nya Rogers (2003) mengelompokan saluran komunikasi menjadi dua. Berikut adalah pembahasan secara lebih lanjut terkait penggunaan beragam saluran komunikasi oleh KICKS

KICKS menggunakan media massa dalam bentuk pemberitaan yang didapatkan dari hasil free coverage dan kerja sama dengan berbagai jenis media massa, baik cetak, broadcast, maupun online. Selain itu KICKS juga memanfaatkan penggunaan new media yang dianggap penting dan memberikan pengaruh besar di zaman yang serba digital saat ini. Penggunaan media massa juga dianggap penting oleh humas KICKS, karena semakin banyak orang yang akan terkena pesan, hal ini sangat diperlukan mengingat banyaknya stakeholder yang ingin diraih KICKS

Di sisi lain, menurut Rogers (2003) saluran komunikasi interpersonal lebih efektif dalam membujuk individu atau unit pengambil keputusan lainnya untuk mengadopsi inovasi, salah satu ciri nya adalah komunikasi ini melibatkan tatap muka antara dua orang atau lebih. KICKS juga menggunakan jenis saluran komunikasi ini dengan cara memberikan penyuluhan maupun edukasi kepada berbagai pihak, baik anggota, masyarakat, opinion leader dan lainnya dengan menggunakan berbagai jenis pendekatan.

Penulis menyimpulkan bahwa untuk memperkenalkan sesuatu yang baru dibutuhkan saluran komunikasi yang tepat dan sesuai. Untuk mendapatkan hasil yang lebih efektif berbagai jenis saluran komunikasi dapat digunakan untuk mendukung peran dan fungsinya satu sama lain.
Selain itu pesan juga harus dibentuk sedemikian rupa agar sesuai dengan saluran komunikasi yang digunakan dan target khalayak yang dituju, karena saluran komunikasi dan target yang berbeda akan membutuhkan strategi komunikasi yang berbeda pula

\section{Waktu}

Elemen ketiga yang diteliti adalah waktu. Sesuai dengan pendapat Rogers (2003), elemen waktu merupakan elemen penting lainnya dalam difusi inovasi. Pengukuran waktu dapat di lihat melalui beberapa faktor, di antaranya adalah melalui proses keputusan inovasi, yang terdiri dari lima tahap. Berikut pembahasan lebih lanjut terkait tahapan tersebut:

Pertama adalah tahap pengetahuan, terjadi ketika individu atau kelompok mengetahui keberadaan suatu inovasi, merupakan tahap awal dari proses keputusan inovasi (Rogers, 2003). Salah satu cara agar individu mengetahui keberadaan inovasi adalah dengan membangun kesadaran bahwa inovasi tersebut dapat mengarah atau menjadi sebuah kebutuhan, di sinilah peran agen perubahan dibutuhkan, untuk mengatasi perbedaan, dengan cara membangun kesamaan dengan target khalayak. Dalam beberapa kasus, ini melibatkan penggunaan opinion leader, tokoh masyarakat, dan perantara pihak ketiga (Rogers, 2003). Dalam kegiatan pengenalan vaksinasi HPV ini, yang berperan sebagai agen perubahan adalah humas KICKS, di mana humas berperan sebagai agen perubahan yang mewakili perusahaan untuk menciptakan suatu perubahan. Di sini salah satu strategi humas KICKS dalam memperkenalkan vaksinasi HPV sebagai suatu inovasi adalah dengan membentuk kampanye kehumasan bernama CegahKankerServiks. Okigbo (2014) berpendapat bahwa penggunaan kampanye kesehatan merupakan salah satu cara terbaik untuk mempromosikan suatu hal di bidang kesehatan. Dalam kampanye ini terdapat beragam kegiatan, dan sejalan dengan pernyataan Rogers, salah satu strategi yang digunakan adalah dengan memaksimalkan penggunaan pemimpin opini sebagai komunikator, yang terdiri dari para ahli, 
dokter, dan selebriti.

Pada tahap pengetahuan, terdapat beberapa informasi penting yang harus disampaikan, di sini unit pengambil keputusan harus dapat mengetahui informasi-informasi dasar terkait inovasi, seperti apa inovasi yang dikenalkan, manfaat, kelebihan, dan sebagainya. Berdasarkan pemaparan S. B. Butar (komunikasi pribadi, 13 Februari, 2019), dan hasil pantauan penulis, humas KICKS sudah menyampaikan pesan-pesan tersebut baik secara langsung maupun melalui beragam media yang ada.

Kedua, tahap persuasi, terjadi setelah individu atau unit pengadopsi lainnya memberikan sikap positif atau negatif terhadap suatu inovasi (Rogers, 2003). Pada tahap ini, individu secara aktif mencari informasi tentang inovasi, di sini yang terpenting adalah pesan apa yang di terima, dan bagaimana menginterpretasikannya (Rogers, 2003). Semua inovasi membawa tingkat ketidakpastian tertentu bagi individu, yang biasanya tidak yakin dengan hasil ide baru dan merasa perlu adanya penguatan sosial. Di sini ada berbagai karakteristik inovasi yang akan menentukan tingkat adopsi, dan beragam karakteristik inovasi tersebut telah dimiliki oleh vaksinasi HPV sebagai suatu inovasi, dan berusaha disampaikan oleh KICKS dengan melakukan control messages.

Control messages dilakukan oleh KICKS pada setiap kegiatannya, baik yang bersifat online maupun offline, dilakukan agar masyarakat dapat menerima pesan secara baik terkait pengenalan vaksinasi HPV dan mempengaruhi pembentukan sikap positif terhadap inovasi yang diperkenalkan. S. B. Butar (komunikasi pribadi, 13 Februari 2019) menjelaskan bahwa pesan yang berusaha disampaikan oleh KICKS pada akhirnya adalah sama, akan tetapi dalam menyampaikan tentunya diperlukan penyesuaian. Dalam memperkenalkan vaksinasi HPV, humas KICKS telah memberikan informasi dan mendukung beragam karakteristik inovasi. Selain itu juga humas KICKS mengolah pesan yang akan disampaikan dengan mempertimbangkan peserta kegiatan, media yang digunakan, komunikator, dan sebagainya guna mempengaruhi pembentukan sikap positif.
Ketiga adalah tahap keputusan, terjadi ketika individu atau unit pengambil keputusan lainnya menentukan akan mengadopsi atau menolak suatu inovasi (Rogers, 2003). Di sini pihak KICKS menyebutkan bahwa tidak semua masyarakat yang terkena pesan memutuskan untuk melakukan adopsi inovasi bahkan beberapa menolak uji coba. Humas KICKS juga menyatakan bahwa pada saat ini kegiatan KICKS masih belum masuk ke dalam tahap implementasi. Akan tetapi sikap positif masyarakat terkait kegiatan KICKS mulai terlihat, hal ini ditunjukan dari antusiasme warga dalam menghadiri kegiatan, permintaan seminar, kesediaan melakukan tes pap smear, banyaknya pihak yang datang untuk melakukan kolaborasi, dan sebagainya.

Keempat, implementasi, terjadi ketika individu atau unit pengambilan keputusan lainnya menggunakan inovasi, pada tahap ini terdapat perubahan perilaku yang jelas karena suatu ide, pemikiran, dan objek benar-benar diterapkan (Rogers, 2003). Terdapat beberapa alasan mengapa masih banyak target khalayak yang belum masuk ke tahap implementasi, salah satunya adalah adanya tipe penerima adopsi yang berbeda-beda, waktu, harga vaksin, dan minimnya pengetahuan masyarakat. A. D. Sjahruddin (komunikasi pribadi, 21 Februari, 2019) selaku dokter spesialis kandungan, juga menyampaikan hal serupa, beliau menjelaskan bahwa permasalahan kanker serviks di Indonesia adalah kenyataan bahwa kanker serviks tidak begitu populer, dan masyarakat belum menganggap isu ini sebagai permasalahan serius. Listyowati (komunikasi pribadi, 12 Februari, 2019) selaku anggota KICKS juga menyatakan bahwa pemerintah belum memberikan perhatian lebih terkait vaksinasi HPV. Disamping pendapatpendapat tersebut, ada juga masyarakat yang sudah melakukan vaksin dan mengakui bahwa salah satu faktor yang mendorongnya adalah informasi yang disampaikan KICKS.

Tahap terakhir adalah konfirmasi, terjadi ketika individu atau unit pembuat keputusan lainnya mencari penguatan dari keputusan yang telah di buat, di sini individu yang tadi nya mengadopsi dapat menolak suatu inovasi dan sebaliknya (Rogers, 2003). Pada tahap ini humas KICKS 
sebagai agen perubahan memiliki peran khusus, jika sebelumnya mereka melakukan beragam usaha agar individu melakukan pengambilan keputusan yang diharapkan, di sini agen perubahan bertanggung jawab menyediakan pesan pendukung kepada individu yang telah melakukan adopsi (Rogers, 2003). Hal ini harus dilakukan secara rutin dan terus menerus, dengan aktif memberikan informasi di berbagai saluran komunikasi, karena sangat memungkinkan bagi individu untuk terkena pesan negatif yang bertentangan dengan keputusan adopsi. Sama halnya seperti tahap keputusan, saat ini kegiatan pengenalan vaksinasi HPV oleh KICKS belum sepenuhnya mencapai tahap ini.

Dari penjelasan di atas penulis melihat bahwa saat ini kegiatan KICKS pada umumnya masih berada pada tahap persuasi. Akan tetapi dalam membentuk dan menyampaikan pesan sendiri, humas KICKS telah melakukan pendekatan dan strategi yang sesuai dengan teori yang ada, baik dari segi pemilihan media, pengolahan pesan, penggunaan opinion leader, dan lainnya. Melalui kegiatan KICKS mulai banyak masyarakat mengetahui keberadaan vaksinasi HPV.

\section{Sistem Sosial}

Sistem sosial merupakan elemen penting lainnya dalam difusi inovasi. Di dalam pembahasan terkait sistem sosial, terdapat beragam topik yang dibahas, diantaranya adalah terkait target khalayak, peran opinion leader dan agen perubahan (Rogers, 2003). Berikut adalah pembahasan lebih lanjut mengenai ketiga hal tersebut:

Di dalam mengenalkan vaksinasi HPV, yang menjadi anggota sistem sosial atau target khalayak adalah seluruh masyarakat Indonesia, khususnya wanita remaja, dewasa dan yang sudah menikah. Selain itu KICKS juga memiliki stakeholder lainnya yang menjadi target komunikasi, diantaranya adalah pemerintah, pembuat kebijakan, pemimpin opini, media, organisasi medis, dan organisasi nonmedis. Sementara untuk melakukan sosialisasi lebih lanjut kepada pria yang juga membutuhkan vaksinasi HPV untuk mencegah penyebaran, dan penyakitpenyakit terkait, S. B. Butar (komunikasi pribadi, 13 Februari 2019) menjelaskan bahwa pada saat ini kegiatan dan edukasi masih di fokuskan kepada perempuan terlebih dahulu, melihat mereka lebih rentan terpapar virus HPV, dan tingginya angka kematian akibat kanker serviks. KICKS melihat bahwa langkah selanjutnya akan lebih menantang ketika harus memperkenalkannya kepada pria.

Menurut Rogers (2003) pemimpin opini merupakan individu atau kelompok yang menyediakan informasi juga saran terkait inovasi kepada anggota sistem sosial. Apa yang dilakukan dan dikatakan oleh pemimpin opini terkait suatu inovasi dapat menjadi bahan pertimbangan penting bagi individu atau unit penerima inovasi lainnya. Dalam kegiatan KICKS, salah satu strategi utama yang digunakan adalah dengan memaksimalkan peran pemimpin opini dalam memperkenalkan inovasi. Terdapat beberapa pemimpin opini yang secara aktif terlibat, semuanya memiliki peran utama sebagai komunikator dan perpanjangan tangan. Pertama adalah duta kanker serviks, terdiri dari beberapa selebritis Indonesia, diantaranya adalah Wulan Guritno, Dewi Sandra, Prilly Latuconsina, Syifa Hadju, Melly Goeslaw, Dewi Sandra, Bunga Jelitha yang mewakili Puteri Indonesia, serta pasangan Ruben Onsu dan Sarwendah. Peran duta kanker serviks dianggap penting dalam membantu menyebar luaskan pesan pengenalan vaksinasi HPV.

Selain duta kanker serviks, pemimpin opini lainnya yang ikut terlibat adalah beragam organisasi, baik organisasi medis maupun nonmedis. Seperti pada gambar 1 merupakan beberapa kegiatan KICKS yang melibatkan opinion leader di dalamnya.

Disamping kedua pihak ini, para dokter dan ahli kandungan juga memiliki peran sebagai pemimpin opini, dengan secara aktif ikut membantu melakukan penyebaran pesan. Hal ini sejalan dengan hasil penelitian Ocviyanti \& Handoko (2013) yang menyatakan bahwa sudah seharusnya Indonesia melakukan upaya program pencegahan kanker serviks dengan melibatkan para ahli dari profesi terkait, di mana setiap dokter khususnya dokter umum sebagai tenaga kesehatan utama dalam layanan kesehatan primer harus segera melakukan edukasi dan pemberian pelayanan pencegahan kanker serviks.

Rogers (2003) mendefiniskan agen perubahan 

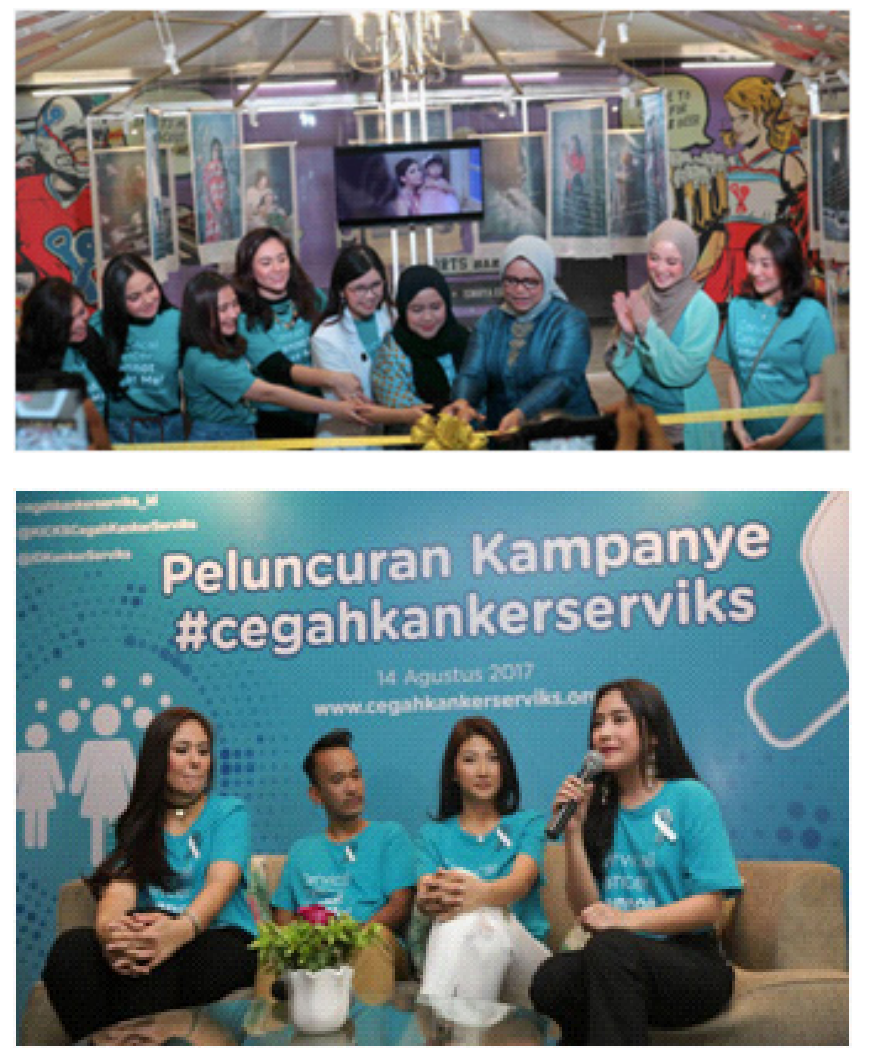

Gambar 1. Kegiatan KICKS Dengan Duta Kanker Serviks

Sumber: Koalisi Indonesia Cegah Kanker Serviks, n. d \& Akto, 2017

sebagai seorang profesional yang dapat membentuk strategi juga taktik guna mempengaruhi proses adopsi yang diinginkan. Semakin banyak pihakpihak ini berpartisipasi membagikan keyakinan terhadap inovasi, maka tingkat penerimaannya akan semakin besar. Dalam kegiatan pengenalan vaksinasi HPV oleh KICKS, yang berperan sebagai agen perubahan adalah humas KICKS. Hal ini sejalan dengan salah satu peran humas menurut Fariani \& Aryanto (2009), yang menjelaskan bahwa humas berperan sebagai agen perubahan yang mewakili perusahaan untuk menciptakan suatu perubahan. Menurut Rogers (2003), agen perubahan pada umumnya adalah seorang profesional yang dapat membentuk strategi juga taktik guna mempengaruhi proses adopsi yang diinginkan. Sesuai dengan penjelasan yang ada, salah satu strategi atau taktik yang dilakukan oleh humas KICKS dalam memperkenalkan vaksinasi HPV sebagai suatu inovasi adalah dengan membentuk kampanye kehumasan bernama CegahKankerServiks.
Berdasarkan hasil analisis tersebut dapat disimpulkan bahwa dalam memperkenalkan vaksinasi HPV, salah satu strategi atau taktik yang dilakukan adalah dengan memaksimalkan penggunaan agen perubahan, opinion leader, tokoh masyarakat, dan perantara pihak ketiga.

\section{Hambatan dan Solusi}

Adapun hambatan yang dihadapi oleh KICKS dalam mengenalkan vaksinasi HPV adalah berupa belum selesainya tahapan dalam proses keputusan inovasi karena adanya tipe penerima adopsi yang berbeda-beda dan jangka waktu kegiatan yang masih dikategorikan baru, harga vaksin yang masih tergolong mahal, dan belum maksimalnya penerapan karakteristik inovasi dalam mengenalkan vaksinasi HPV. Hambatan serupa juga dijelaskan dalam beberapa penelitian sebelumnya, diantaranya Hartoyo dan Supriadi (2015) yang menjelaskan bahwadalam proses keputusan inovasi, tipe penerima adopsi yang berbeda akan memerlukan upaya dan waktu yang berbeda pula. Adawiyah (2017) juga menjelaskan hal serupa dengan menerangkan bahwa individu memiliki karakteristik yang beragam dan masingmasing memiliki usaha yang berbeda, sehingga kecepatan mereka dalam mengadopsi inovasi tidak akan sama.

Hambatan tersebut dapat diatasi apabila KICKS terus mengembangkan dan memberikan infomasi yang sesuai dan menarik bagi para target khalayak dengan menggunakan berbagai saluran komunikasi seiring berjalannya waktu. Hal tersebut diantaranya dapat dilakukan dengan memperluas komunikasi interpersonal di daerah luar JABODETABEK, memaksimalkan penggunaan early adopter sebagai komunikator, memberikan kesempatan uji coba secara langsung disamping uji coba perwakilan, membentuk kegiatan dengan pendekatan keluarga, dan menyampaikan informasi dari beragam sudut pandang, baik agama, hukum, sosial dan medis.

\section{SIMPULAN}

Dari hasil penelitian di atas dapat disimpulkan bahwa, dalam memperkenalkan vaksinasi HPV humas KICKS telah mempertimbangkan elemenelemen utama dalam difusi inovasi, yang terdiri 
atas inovasi, saluran komunikasi, waktu, dan sistem sosial. Humas KICKS menggunakan berbagai jenis saluran komunikasi yang saling mendukung perannya satu sama lain, yaitu media massa, new media, dan komunikasi interpersonal sebagai saluran komunikasi. Pesan diolah dengan mempertimbangkan beragam karakteristik inovasi, yang terdiri atas relative advantage, compatibility, complexity, trialability, observability. Selain itu, guna mempengaruhi proses adopsi yang di inginkan humas KICKS membentuk strategi juga taktik dengan memaksimalkan penggunaan opinion leader, yang mayoritas terdiri dari selebriti Indonesia.

Saat ini pengenalan vaksinasi HPV oleh KICKS pada umumnya baru masuk kedalam tahap keputusan di dalam proses keputusan inovasi, karena adanya tipe penerima adopsi yang berbeda-beda dan jangka waktu kegiatan yang masih dikategorikan baru. Penggunaan elemen difusi inovasi sebagai fokus penelitian dan temuan serupa juga di bahas dalam penelitian sebelumnya oleh Hartoyo dan Supriadi (2015), yang berjudul "Aktivisme Sosial Melalui Penggunaan Media Sosial: Studi Kasus Asosiasi Ibu Menyusui Indonesia (AIMI)", menjelaskan bahwa proses dalam komunikasi kesehatan dapat tergambar dalam tahapan innovation-decision process dan pada akhirnya tipe penerima adopsi yang berbeda akan memerlukan upaya yang berbeda pula.

Adapun beberapa faktor penghambat pengenalan vaksinasi HPV oleh KICKS adalah berupa masih belum selesainya tahap keputusan inovasi, harga vaksin yang masih tergolong mahal, dan belum maksimalnya penerapan karakteristik inovasi dalam mengenalkan vaksinasi HPV. Hambatan tersebut masih dapat diatasi apabila KICKS terus mengembangkan dan memberikan infomasi yang sesuai dan menarik bagi para target khalayak dengan menggunakan berbagai saluran komunikasi seiring berjalannya waktu.

\section{DAFTAR PUSTAKA}

Adawiyah, Cut. Rabiatul. (2017). Urgensi Komunikasi dalam Kelompok Kecil untuk Mempercepat Proses Adopsi Teknologi Pertanian. Forum Penelitian Agro Ekonomi, 35(1), 59-74.
Afrizal, M. A. (2014). Metode Penelitian Kualitatif: Sebuah Upaya Mendukung Penelitian Kualitatif dalam Berbagai Disiplin Ilmu. Jakarta, Indonesia: PT Raja Grafindo Persada.

Anggani, Calisca Hardiana. (2014). Pengaruh Program Kampanye "Say No To Plastic Bag" oleh The Body Shop Tehadap Partisipas Masyarakat. Wacana: Jurnal Ilmiah Ilmu Komunikasi, 13(2), 155-177.

Ayuningtyas, D \& Sutrisnawati, N. N. D. (2018). Indonesia's Readiness to Implement the HPV Vaccine Mandatory for School Age. Health Science Journal of Indonesia, 9(2).

Budiwati, Margareta. (2012). Perancangan Kampanye Sosial Cegah Kanker Serviks pada Remaja Melalui Desain Komunikasi Visual. UNS-F.SSR Jurnal Desain Komunikasi Visual Adiwarna, 1(4).

Benita, Nydia. Rena. (2012). Pengaruh Penyuluhan Terhadap Tingkat Pengetahuan Kesehatan Reproduksi Pada Remaja Siswa SMP Kristen Gergaji. Program Pendidikan Sarjana Kedokteran, Fakultas Kedokteran, Universitas Diponegoro, Semarang, Indonesia.

Bungin, Burhan. (2010). Penelitian Kualitatif: Komunikasi, Ekonomi, Kebijakan Politik, dan Ilmu Sosial Lainnya ( ${ }^{\text {th }}$ ed). Jakarta, Indonesia: Kencana.

Centers for Disease Control and Prevention. (2013). Comprehensive Cervical Cancer Control: A guide to essential practice $(\mathrm{C} 4$ GEP). By (https://www.cdc.gov/vaccines/ hcp/vis/index.html).

Departemen Kesehatan. n. d. Buletin Jendela Data dan Informasi Kesehatan. (2015). By (http://www.depkes.go.id/download. php?file=download/pusdatin/buletin/ buletin-kanker.pdf).

Dewi, Makassari. (2017, Januari 19). Sebaran Kanker di Indonesia, Riset Kesehatan Dasar 2007. Indonesian Journal of Cancer, 11(1), 1-8.

Fariani, Silvia. Rita \& Aryanto, Widodo. (2009). Panduan Praktis PR. Jakarta, Indonesia: PT Elex Media Komputindo. 
Ghebreyesus, Tedros. Adhanom. (2018). Cervical Cancer: An NCD We Can Overcome. World Health Organization. By (http://www.who. int/reproductivehealth/DG_Call-to-Action. pdf).

Hartoyo, Nunik Maharani \& Supriadi, Dandi. (2015). Aktivisme Sosial Melalui Penggunaan Media Sosial: Studi Kasus Asosiasi Ibu Menyusui Indonesia (AIMI). Jurnal Kajian Komunikasi, 3(1), 1-11.

HPV Information Center. (2018). Indonesia Human Papilloma Virus and Related Cancers, Fact Sheet. By (https://hpvcentre.net/statistics/ reports/IDN_FS.pdf)

International Pharmaceutical Manufacturers Group. n. d. Dilarang Percaya 4 Mitos Kanker Ini. By (https://www.ipmg-online. com/index.php? modul=berita\&cat=BMedi a\&textid=281501086421).

Koalisi Indonesia Cegah Kanker Serviks. n. d. Tentang KICKS. By (https:// cegahkankerserviks.org/tentang-kicks)

Moleong, Lexy. J. (2014). Metodologi Penelitian Kualitatif. Bandung, Indonesia: PT Remaja Rosdakarya.

National Cancer Institute. (2016). The 'Crisis' of Low HPV Vaccination Rates: A Conversation with Dr. Noel Brewer. By (https://www.cancer.gov/newsevents/cancer-currents-blog/2016/hpvvaccination-rates).

Ocviyanti, Dwiana. dan Handoko, Yohanes. (2013+, Januari). Peran Dokter Umum dalam Pencegahan Kanker Serviks di Indonesia. J Indon Med Assoc, 63(1).

Okigbo, Charles. C. (2014). Strategic UrbanHealth Communication. North Dakota, Fargo: Springer.

Parrott, Roxanne. (2009). Talking About Health Why Communication Matters. West Sussex, Inggris: Blackwell Publishing.

Rahmadiana, Metta. (2012). Komunikasi Kesehatan: Sebuah Tinjauan. Jurnal Psikogenesis, 1(1), 88-94.

Remes, Pieter., Selestine, Veronica., Changalucha, John., Ross, David. A., Wight, Daniel.,
Sanjose, S. D., Kapiga, S., Hayes, R. J \& Jones, D. W. (2012). A qualitative study of HPV vaccine acceptability among health workers, teachers, parents, female pupils, and religious leaders in northwest Tanzania. Vaccine, 3(30), 5363-5367.

Rizal. Fahrul. (2012). Penerapan Teori Difusi Inovasi dalam Perubahan Sosial Budaya. Hikmah, 6(1), 129-140.

Rogers, Everett. M. (2003). Diffusion of Innovations. Newyork City, NY: The Free Press

Savitri, Astrid. (2015). Kupas Tuntas Kanker Payudara, Leher Rahim dan Rahim. Yogyakarta, Indonesia: Pustaka Baru Press.

Setianto, W. A. (2016). Inovasi e-Health Dinas Kesehatan Kota Surabaya. Jurnal Ilmu Komunikasi, 14(3), 151-164.

Siu, Judy. Yuen-man. (2014). Perceptions of and barriers to vaccinating daughters against Human Papillomavirus (HPV) among mothers in Hong Kong. BMC Women's Health, (hal: 14:73).

Suwarno, Yogi. n. d. Inovasi di Sektor Publik. By (https://www.researchgate.net/ publication/328202667_INOVASI_DI SEKTOR PUBLIK)

Wilujeng, Catur. Saptaning \& Handaka, Tatag. (2017, September). Komunikasi Kesehatan: Sebuah Pengantar. Malang, Indonesia: UB Press.

Wiyanti, Widiya. (2017, 12 Juni). Ini Kisaran Biaya Vaksin HPV, Penangkal Kanker Serviks yang Mematikan. Detik. By (https://health. detik.com/berita-detikhealth/d-3528381/ ini-kisaran-biaya-vaksin-hpv-penangkalkanker-serviks-yang-mematikan)

Yudhani, R. D., Astuti, I., Mustofa, M., Indarto, D \& Muthmainah, M. (2019). Metformin Modulates Cyclin D1 and P53 Expression to Inhibit Cell Proliferation and to Induce Apoptosis in Cervical Cancer Cell Lines. Asian Pacific Journal of Cancer Prevention, 20(6), 1667-1673. 